\title{
Structure, Mechanical Performance, and Dimensional Stability of Radiata Pine (Pinus radiata D. Don) Scrimbers
}

\author{
Jinguang Wei $\left(\mathbb{D},{ }^{1}\right.$ Fei Rao, ${ }^{1}$ Yuxiang Huang $\mathbb{D},{ }^{1}$ Yahui Zhang, ${ }^{1}$ Yue Qi, \\ Wenji Yu $\left({ }^{\circ},{ }^{1}\right.$ and Chung-Yun Hse ${ }^{2}$ \\ ${ }^{1}$ Scrimber Engineering and Technology Research Center of State Forestry Administration, Research Institute of Wood Industry, \\ Chinese Academy of Forestry, Beijing 100091, China \\ ${ }^{2}$ Southern Research Station, USDA Forest Service, Pineville, LA 71360, USA \\ Correspondence should be addressed to Wenji Yu; chinayuwj@126.com
}

Received 17 April 2019; Revised 31 May 2019; Accepted 27 June 2019; Published 10 July 2019

Guest Editor: Changlei Xia

Copyright (c) 2019 Jinguang Wei et al. This is an open access article distributed under the Creative Commons Attribution License, which permits unrestricted use, distribution, and reproduction in any medium, provided the original work is properly cited.

\begin{abstract}
Natural wood has certain advantages such as good processability and high specific strength and thus has been used for millennium as a structural material. But the mechanical performance and water resistance, particularly for fast-growing species, are unsatisfactory for high-end applications. In this study, the "new-type" scrimber technology was introduced to radiata pine (Pinus radiata D. Don) scrimbers. The structure, mechanical properties, and dimensional stability of the scrimber panels were investigated. Results showed that OWFMs as basic units of scrimber had been very even in size and superior permeability. The scrimbers exhibited a threedimensional porous structure, and the porosity had a decrease with increasing density. Both OWFMs and densification contributed to the high performance in terms of mechanical properties and water resistance. The flexural, compressive, and short-beam shearing strength were significantly enhanced with increasing density. As the density was $0.80 \mathrm{~g} \mathrm{~cm}^{-3}$, the flexural strength (MOR) was approximately $120 \mathrm{MPa}$, much larger than many selected wood-based panels. Moreover, the water resistance and dimensional stability also were closely related to the density. At the density of $1.39 \mathrm{~g} \mathrm{~cm}^{-3}$, the water absorption rate and thinness swelling rate of the panels in boiled water were only $19 \%$ and $5.7 \%$, respectively.
\end{abstract}

\section{Instruction}

Natural materials have advantages of sustainability, renewability, and low cost and are gradually overtaking synthetic materials, which suffer from high density, environmental problems, complex processes, and high cost [1]. Wood is recognized as an excellent natural material [2]. It has high specific strength and stiffness, good processability, and favorable aesthetics and has been widely used in the fields of paper [3], package [4], furniture [5], and building [6]. Due to the shortage of high-quality wood, fast-growing wood species such as radiata pine (Pinus radiata D. Don) has been attracting attentions over the world $[7,8]$. These woods have many advantages such as rapid growth, easy harvesting and processing, and acceptable tolerance to various site conditions. However, they also have inherent disadvantages including low density and natural defects and thus unsatisfactory mechanical properties $[9,10]$. They are thus usually used in the fields of paper, package, low-end furniture, and other low-value products. For a broader utilization in high addedvalue application, those disadvantages need to be overcome.

Various methods, such as chemical modification, heat treatment, and densification, have been developed to obtain better properties, and pronounced effects have been demonstrated [11-16]. Among them, processing fast-growing wood into scrimber is a promising method, in which the logs with small diameters are typically crushed to form interconnected long strands by a scrimming machine [17]. The strands exhibit three-dimensional network structure comprising the dispersed fiber bundles, which not only facilitates adhesive impregnation but also reduces the effects of natural defects on product performance [18]. The scrimber density can be adjusted in the range from 0.85 to $1.2 \mathrm{~g} \mathrm{~cm}^{-3}$ to meet the application requirement, and the mechanical performance is superior to that of many existed wood-based panels [19]. However, those bundles are very uneven in size, which gives 
rise to many drawbacks for scrimber products. The density variation, for example, leads to poor end-product quality such as curl, deformation, and rough surface.

To address these problems, $\mathrm{Yu}$ and his coworkers improved the preparation method $[20,21]$. In the new method, round wood was first peeled into thick veneers and then split into the oriented wood fiber mats (OWFMs) by a fluffing machine. The mats had very even fiber strands, which significantly improved the adhesive distribution and the density uniformity [22]. Since a series of uniform linearshaped cracks were formed on the surface, the mat had better permeability than the bundles prepared by the old method. These improvements contributed to the achievement of excellent performance in terms of mechanical strength and water resistance. In addition, the scrimber panels (named new-type scrimber) preserved the structural characteristics of natural wood (e.g., fiber orientation and appearance), and it could safely be processed as the logs, even with high design strength and availability in large dimensions [23]. The new method has been successfully applied to a hardwood poplar wood (Populus ssp.) in China, but few attempts have been made to apply to softwood [20].

Radiata pine is a most widely planted fast-growing softwood in the Southern Hemisphere. It has been a mainstay of the forest economy and reduced cutting pressure on native forests in Australia, New Zealand, Chile, Argentina, Uruguay, Kenya, and the Republic of South Africa [24]. Like other softwoods, it has low density in the range from 0.40 to $0.50 \mathrm{~g}$ $\mathrm{m}^{-3}$ and unsatisfactory mechanical properties. For example, the pine with a mean density of $0.48 \mathrm{~g} \mathrm{~cm}^{-3}$ has an ultimate bending strength of approximately $75 \mathrm{MPa}$ and modulus of elasticity of approximately $9 \mathrm{GPa}$ [25], which cannot meet the requirement of high-end applications. The emergence of "new-type" scrimber technology has great possibility of improving pine wood performance and extending the application fields.

In this study, the process method of new-type scrimber was used to fabricate pine scrimber. The microstructure, mechanical properties, water resistance, and dimensional stability were investigated, and the effect of density also was discussed. The objective of this study is to explore the extensive applicability of the new-type scrimber technology and to develop high-performance wood materials using inexpensive and abundant pine wood.

\section{Material and Method}

2.1. Materials. Radiata pine with a diameter of $\sim 450 \mathrm{~mm}$ and a basic density of $0.42 \mathrm{~g} \mathrm{~cm}^{-3}$ was purchased from Linyi Jinshan Wood Co., Ltd. (China). Phenol formaldehyde (PF) resin with the number-average molecular weight of 596, solid content of $47.49 \%$, viscosity of $41 \mathrm{mPa} \cdot \mathrm{s}$ at $25^{\circ} \mathrm{C}$, and $\mathrm{pH}$ of 10.22 was applied by Dynea Guangdong Co., Ltd. Other reagents were of chemical grade throughout the experiment and purchased from Aldrich Chemical (Shanghai) Co., Ltd.

\subsection{Methods}

2.2.1. Scrimber Fabrication. The pine log without barks was used as raw material to prepare the oriented wood fiber mats according to the reported method [20], and the scrimbers were obtained through laminating the mats impregnated with PF resin. In brief, round wood was softened in the boiled water and then peeled into the flat veneers with $6 \mathrm{~mm}$ in thickness using the spindleless veneer lathe (Xuanjin, China). The veneers were split along the wood growth direction by a fluffing machine into the fiber mats. The mats were dried in an oven at $70^{\circ} \mathrm{C}$ until the moisture content was approximately $10 \%$. The dried mats were impregnated with dilute PF resin (solid content of $10 \mathrm{wt} . \%$ ) and the weight gain was $13 \mathrm{wt} . \%$ based on the weight of dried mats. The wet mats with resin were air-dried until the moisture content reached $11 \mathrm{wt} . \%$. A certain weight of the dried mats with resin was assembled along the grain direction in the mold. Hot pressing was conducted at $145^{\circ} \mathrm{C}$ for $30 \mathrm{~min}$ on a Model 3856 thermocompressor (CARVER, USA) to obtain the board (300 $\times 200 \times 20 \mathrm{~mm}^{3}$ ). By changing the mat weight, a series of scrimber boards were obtained with various densities (i.e., $0.80,1.01,1.20$ and $1.39 \mathrm{~g} \mathrm{~cm}^{-3}$ ). Prior to testing, the scrimber boards were conditioned in a chamber at $65 \pm 5 \%$ relative humidity (RH) at $20 \pm 2^{\circ} \mathrm{C}$ for two weeks.

2.2.2. Water Loading of OWFMs. The permeability of thick veneers and OWFMs were characterized by the water loading rate $(W L R)$. The samples were immersed in water at room temperature for $5 \mathrm{~min}$ then taken out and placed vertically for another $5 \mathrm{~min}$. The rate was calculated by

$$
W L R=\left(m_{2}-m_{1}\right) \times \frac{100 \%}{m_{1}},
$$

where $m_{1}$ and $m_{2}$ were the weights of samples before and after water impregnation, respectively.

2.2.3. Morphological Observation. Microstructure of transverse sections was observed using a S3400 scanning electron microscope (SEM) (Hitachi, Japan) at an accelerating voltage of $5.0 \mathrm{kV}$. Samples were made of the same wood at the same position to ensure the comparability. Prior to observation, the surface was smoothed with a sliding microtome and then sputter-coated with a thin layer of gold.

2.2.4. Determination of Porosity. The apparent density $\left(\rho_{\mathrm{a}}\right)$ was considered as the ratio between the mass of a sample and the total volume it occupied. The substantial density $\left(\rho_{\mathrm{s}}\right)$ was defined as the ratio between the mass of the sample and the actual volume it occupied. $\rho_{\mathrm{s}}$ was measured by an AccuPyc 1330 pycnometer (Micromeritics, USA) at $22 \pm 0.5^{\circ} \mathrm{C}$. For accuracy, the sample was transversely cut into small slices with $2 \mu \mathrm{m}$ in thickness and at least five duplicates were measured for each sample. The porosity $(\varepsilon)$ was defined as the fraction of the volume of voids over the total volume of the sample, and it was calculated by [26]

$$
\varepsilon=\left(1-\frac{\rho_{\mathrm{a}}}{\rho_{s}}\right) \times 100 \%
$$

2.2.5. Mechanical Testing. The flexural and compressive properties of scrimber samples were tested according to the standard of GB/T 17657-2013 and the short-beam shearing 


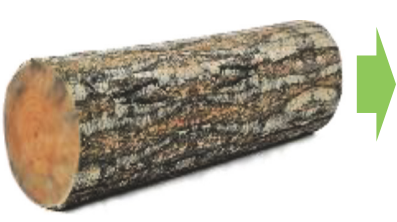

(a) Pine wood

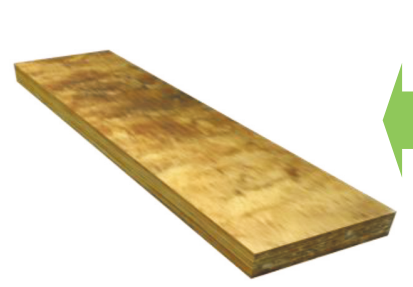

(h) Scrimber

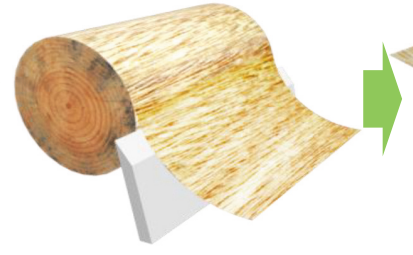

(b) Cutting

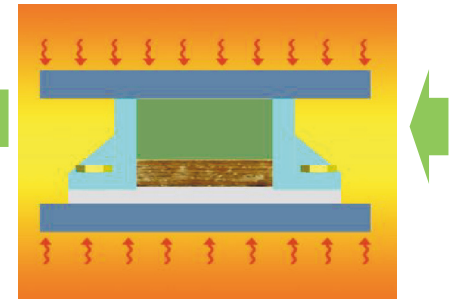

(g) Hot pressing

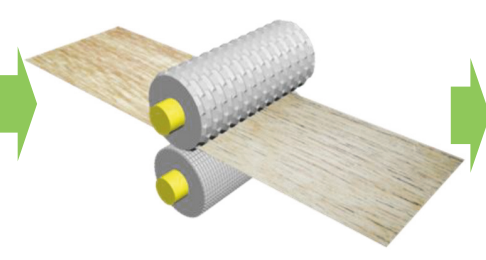

(c) Splitting

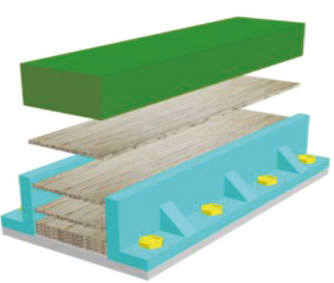

(f) Assembling

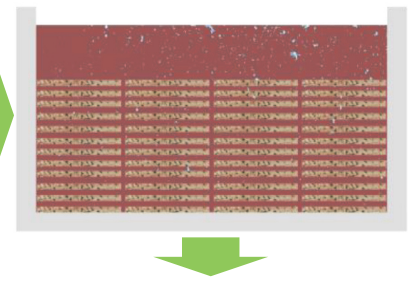

(d) Impregnation

FIGURE 1: Diagrams of scrimber preparation.

according to the standard of GB/T 20241-2006. All tests were performed on a CMT5105 universal testing machine (MTS systems, China). For each density, at least eleven samples were tested to ensure good reproducibility.

2.2.6. Water Resistance. The water absorption rate (WAR), thickness swelling rate (TSR), and width swelling rate (WSR) of scrimber samples were measured according to the standard GB/T 30364-2013. The samples were boiled for 4 hours, dried at $63 \pm 3^{\circ} \mathrm{C}$ for 20 hours and boiled for another 4 hours. WAR was calculated by

$$
W A R=\left(w_{2}-w_{1}\right) \times \frac{100 \%}{w_{1}},
$$

where $w_{1}$ and $w_{2}$ were the sample weight before and after boiling, respectively. And TSR was calculated by

$$
\operatorname{TSR}=\left(t_{2}-t_{1}\right) \times \frac{100 \%}{t_{1}},
$$

where $t_{1}$ and $t_{2}$ were the thickness of the sample before and after boiled, respectively. Similarly, WSR was calculated as well.

\section{Results and Discussion}

3.1. Scrimber Formation. Figure 1 shows the diagrammatical process of pine scrimbers, which mainly involves rotarycutting of round wood, directional splitting of thick veneers, impregnating with phenolic resin, and hot pressing. The rotary-cut veneers had flat surface and uniform thickness. As directionally split by the fluffing machine, the veneers turned into web-like fiber mats. As like the flat veneer, the mat preserved a whole sheet with well-distributed density. Compared to the strands obtained directly from the crushed log, the mat surface was flatter, and thus it was easier for layup. In addition, there existed a series of dotted and linear-shaped cracks on the mat surface (Figure 2(b)), which offered many paths for liquid impregnation. The water loading rate of OWFMs was 161.34 wt.\%, which was four folds more than that of the flat (or split-free) veneers (Figure 2(c)). Apart from enhanced permeability, low-molecular-weight PF resin used in this study allowed more adhesive penetrating into the lumens and cell walls. It has been proven that phenolic resin can prominently soften wood cell walls and decrease the Young's modulus (MOE) of wood fibers [27]. More resin could facilitate the collapse of cell walls at lower pressure. Heat also can effectively soften the wood and make the pressing easier. In comparison with the cold-pressing and hot-curing method, the hot pressing saved more than $90 \%$ of the time, which were obtained from the reported literature $[28,29]$.

3.2. Microstructure. The cross-section surfaces of scrimbers were observed at microscopic scales, and their micrographs are shown in Figure 3. All scrimbers exhibited a threedimensional porous structure consisting of axial tracheids with fair dense cell walls. But there still existed the difference between them due to various densities. For the scrimbers with a density of $0.8 \mathrm{~g} \mathrm{~cm}^{-3}$, the cell walls had less deformation along the pressing direction (Figure 3(a)). Some walls were divided from each other and the narrow gaps were formed, which may arise from the intercellular bonding destruction during the hot pressing. As the density increased, the cell shape became more and more irregular. For the scrimber with $1.2 \mathrm{~g} \mathrm{~cm}^{-3}$, almost cell walls collapsed layer by layer, accompanied by the walls cracking (Figure 3(c)). When the density reached $1.39 \mathrm{~g} \mathrm{~cm}^{-3}$, a majority of lumens were filled with the collapsed walls, and most walls had been barely distinguished (Figure 3(d)).

Figure 4 shows that the average porosity of scrimbers sharply decreased with increasing density. The porosity decreased from $68 \%$ for the pine wood to $46 \%$ for the scrimbers with a density of $0.80 \mathrm{~g} \mathrm{~cm}^{-3}$. In the case of the scrimbers with $1.39 \mathrm{~g} \mathrm{~cm}^{-3}$, the porosity reached approximately $2.11 \%$, which was only $3 \%$ of that of pine wood. 


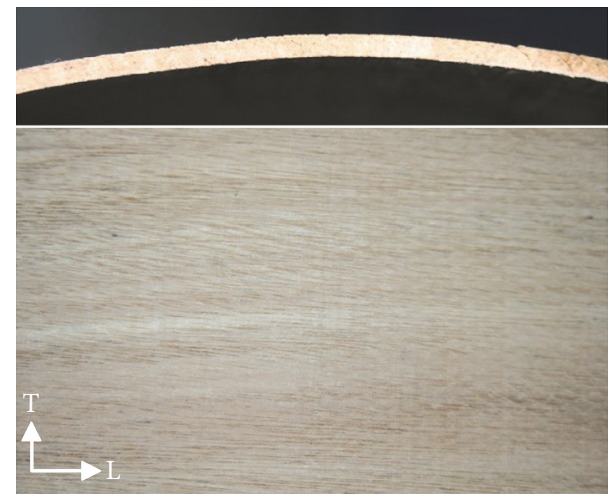

(a)

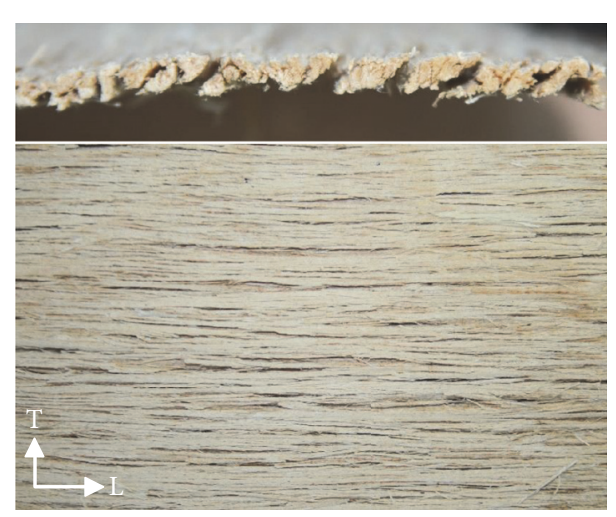

(b)

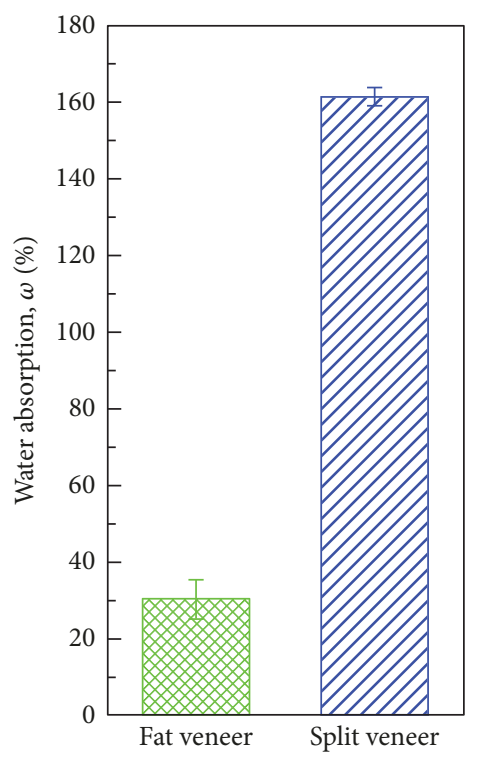

(c)

FIGURE 2: Surface macrograph of (a) the flat veneer and (b) OWFM, and their water loading rates.

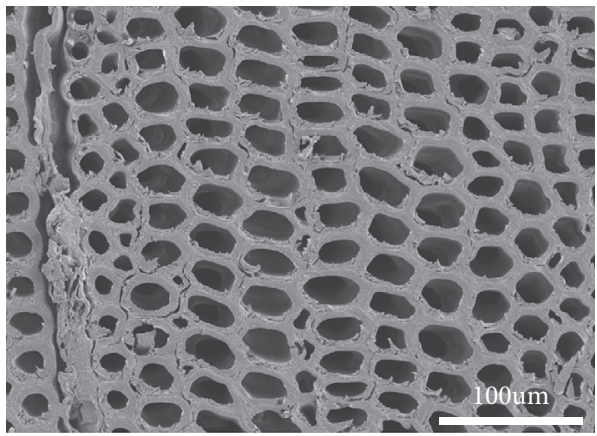

(a)

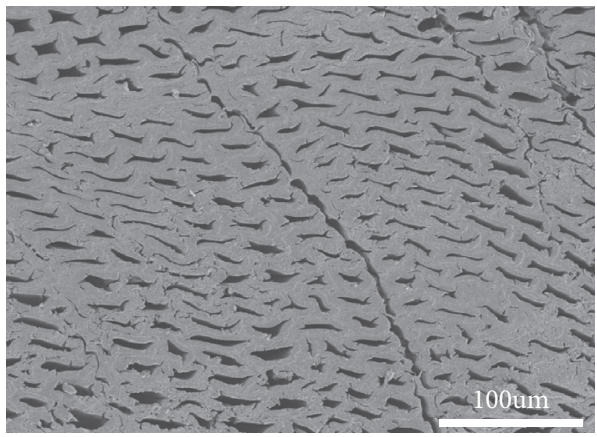

(c)

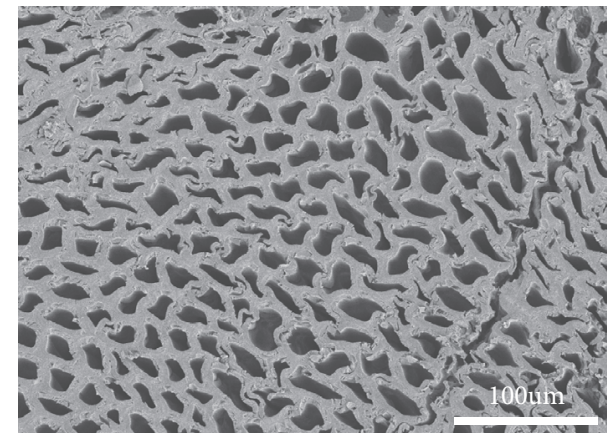

(b)

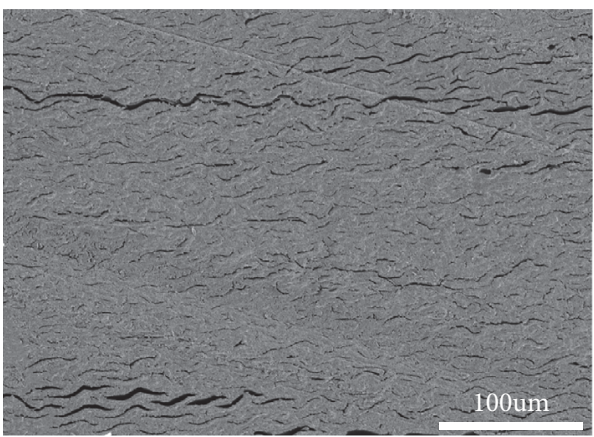

(d)

FIGURE 3: SEM micrographs of scrimbers with density of (a) 0.80 , (b) 1.01 , (c) 1.20 , and (d) $1.39 \mathrm{~g} \mathrm{~cm}^{-3}$.

Such low porosity may be conducive to the improvement of physical and mechanical properties.

3.3. Mechanical Properties. Figure 5 shows the strength and stiffness of scrimbers as a function of density. The flexural strength (MOR) and modulus (MOE) increased with increasing density. At the density of $0.80 \mathrm{~g} \mathrm{~cm}^{-3}$, the scrimber had approximately $120 \mathrm{MPa}$ in MOR, which was much larger than most selected wood-based panels as presented in Figure 6, such as pine plywood [30], pine oriented strand board (OSB) [31], kenaf particleboard [32], and wood-polymer composite (WPC) [33]. The strength almost came up to that of poplar scrimbers at the same density, which were prepared by the cold-pressing and hot-curing method [20]. As the density was 


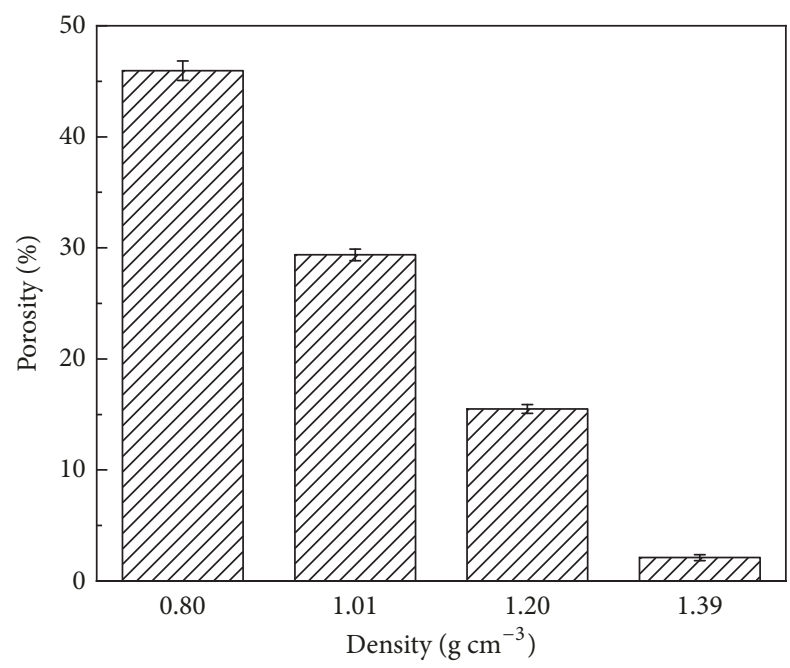

FIGURE 4: Porosity of scrimbers with varying densities.

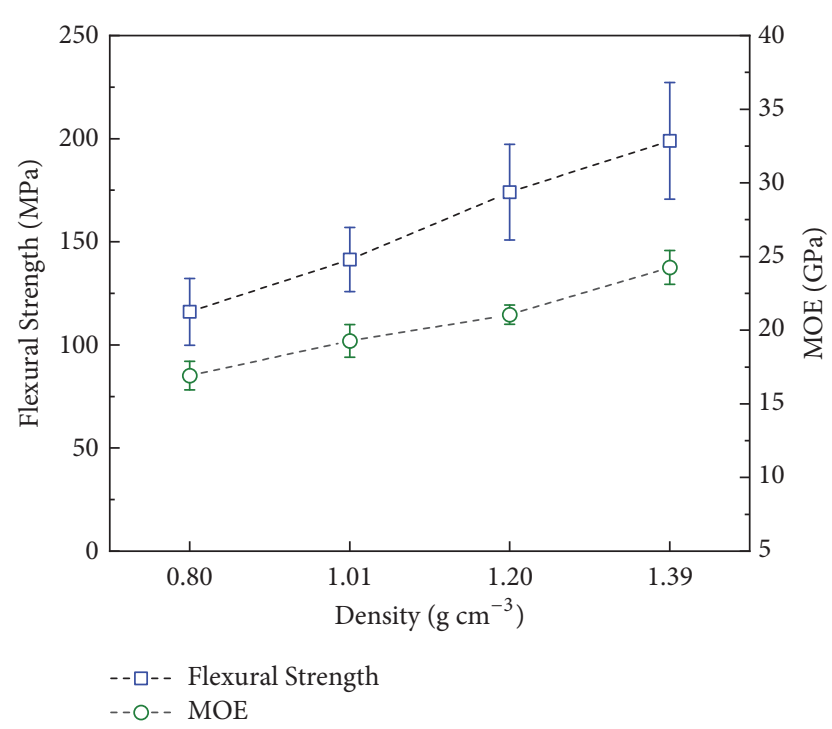

FIGURE 5: Flexural properties of scrimbers with various densities.

$1.01 \mathrm{~g} \mathrm{~cm}^{-3}$, the strength surpassed that of pine compressed wood [34]. When the density was equal to $1.39 \mathrm{~g} \mathrm{~cm}^{-3}$, MOR was up to $198.92 \mathrm{MPa}$ on average, which was $71 \%$ higher than that of scrimers at $0.80 \mathrm{~g} \mathrm{~cm}^{-3}$. Meanwhile, the modulus had an increase by about $7.5 \mathrm{GPa}$ in comparison with that at $0.80 \mathrm{~g}$ $\mathrm{cm}^{-3}$.

Compressive and short-beam shearing properties also were enhanced with an increase of density (Figure 7). The compressive strength was $87 \mathrm{MPa}$ at the density of $0.8 \mathrm{~g}$ $\mathrm{cm}^{-3}$, which was $70 \%$ larger than that of GluBam prepared by Xiao et al. [35]. As the density reached $1.39 \mathrm{~g} \mathrm{~cm}^{-3}$, the strength increased to $154 \mathrm{MPa}$ and the specific strength was approximately $110 \mathrm{MPa} \mathrm{g}^{-1} \mathrm{~cm}^{3}$. Similarly, the shortbeam shearing strength, which reflects the bonding quality of laminated panels [36], increased with increasing density, but maintained at $21 \mathrm{MPa}$ as the density was $1.20 \mathrm{~g} \mathrm{~cm}^{-3}$ or more.

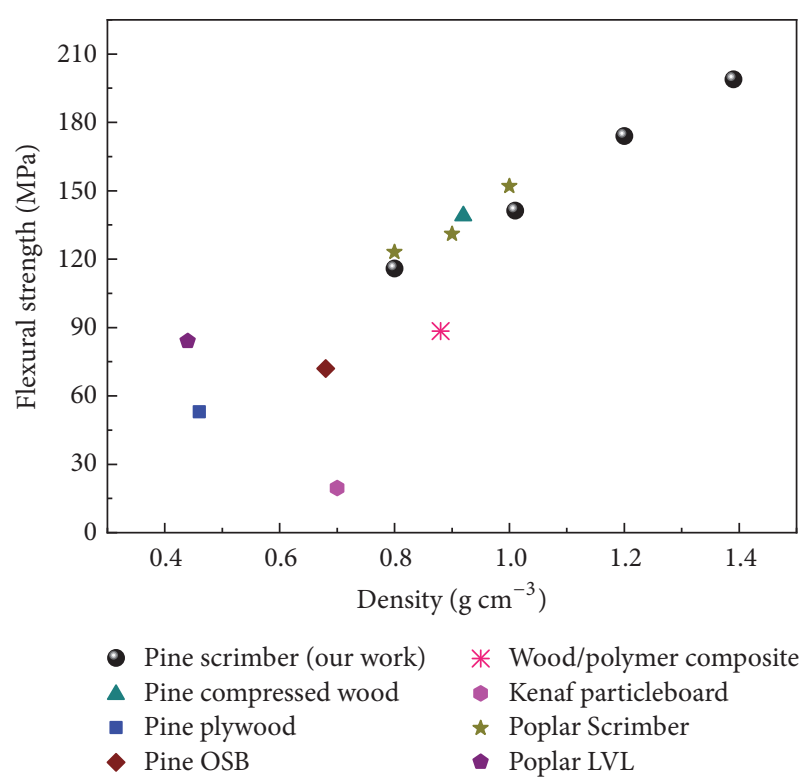

FIgURE 6: Comparison of flexural strength between the scrimbers and selected wood-based panels.

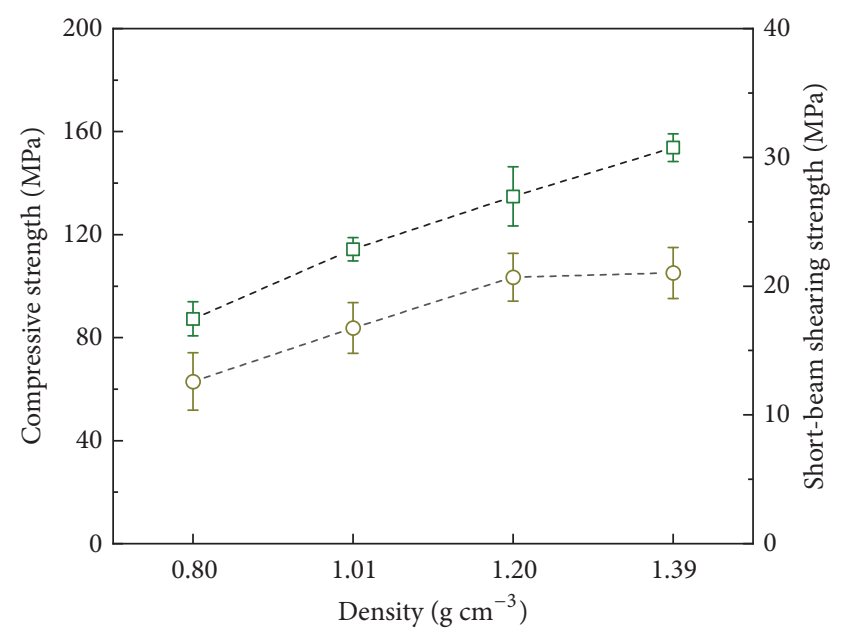

-- $\square-$ - Compressive strength
--০-- Short-beam shearing strength

FIgURE 7: Compressive and short-beam shearing properties of scrimbers with various densities.

These remarkable improvements were ascribed to the superior feature of OWFMs and the densified structure of scrimbers. The high permeability of OWFMs facilitated the bonding behavior between wood fibers and PF resin, thus improving the bonding strengths. Besides, the strands increased the contact area between the fiber and PF resin and between each fiber, which benefited the stress transferring. In general, the mechanical properties of lignocellulosic composites manily depended on the structure and strength of cellulosic fibers, which bears the exterior loads [37, 38]. The structural densification increased the fiber content per unit volume, resulting in high endurance capacity for these scrimbers. 


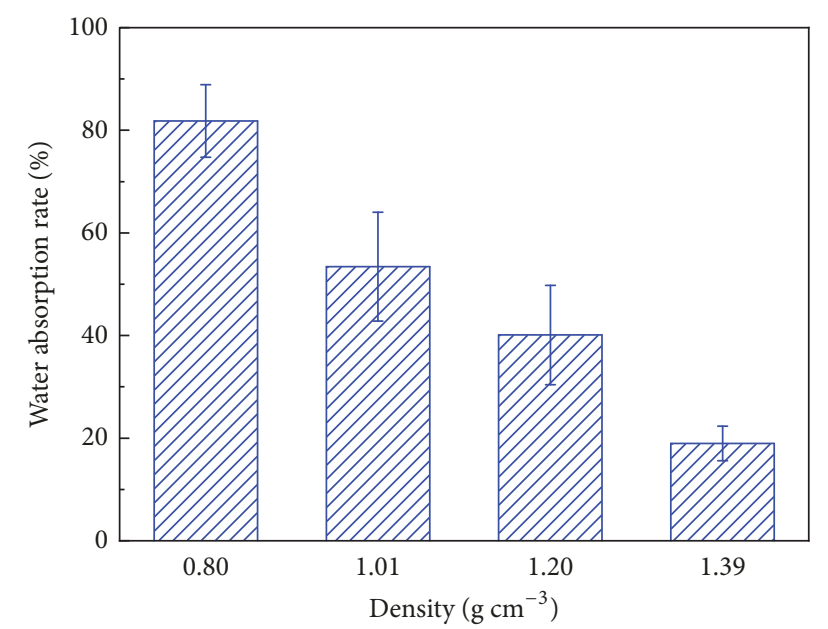

FIGURE 8: Water absorption rate of scrimbers with different densities.

3.4. Water Absorption and Dimensional Stability. The water absorption rate of scrimbers in boiled water is depicted in Figure 8 . With increasing density, the absorbed water gradually decreased. When the density was $0.80 \mathrm{~g} \mathrm{~cm}^{-3}$, the absorbed water was $81.82 \%$ based on the weight of oven-dried sample, which was less than half that of pine wood (i.e., 176\%). In respect to the scrimbers at the density of $1.39 \mathrm{~g} \mathrm{~cm}^{-3}$, the water absorption rate was as low as $19 \%$, which was the least value among the scrimbers in this work. Besides the molecular adsorption of cell walls, the pronounced discrepancy can be ascribed to the different porosities. The lumens offered considerable conveying channels and storage space to water [39]. Low porosity reflected fewer channels and space within the scrimber, leading to less absorbed water. Moreover, the lower the density was, the lower the porosity was, followed by less water absorbed by the scrimbers. These results suggested that the scrimbers with high density had better capacity of water resistance.

The absorbed water could cause the deformation recovery of scrimbers. As presented in Figure 9, the thickness swelling rate at the density of $0.80 \mathrm{~g} \mathrm{~cm}^{-3}$ was $22 \%$, which was three times as much as that of pine wood (i.e., 7\%). Besides the cell wall swelling, the recovery of compressed wood cells contributed to the great discrepancy. In the preparation process of our case, the wood cells were compressed, accompanied by extra internal stress [40]. When the scrimber was placed in the hygrothermal condition, the compressed cells tended to recover to the initial shape. In the macroscale, the recovery of cell deformations appeared as the thickness swelling. Furthermore, as the density increased, some cell walls crashed, accompanied by tiny cracks on the wall. The rate trended to decline due to the poor ability of cell recovery, confirmed by only $5.7 \%$ in thickness swelling the scrimbers at the density of $1.39 \mathrm{~g} \mathrm{~cm}^{-3}$ had.

Compared to the thickness, the width had much less swelling rate under any density. It could be ascribed to the fact that the wood cells were mainly compressed along the thickness direction during the hot pressing, while less deformation occurred in the width direction. In the case,

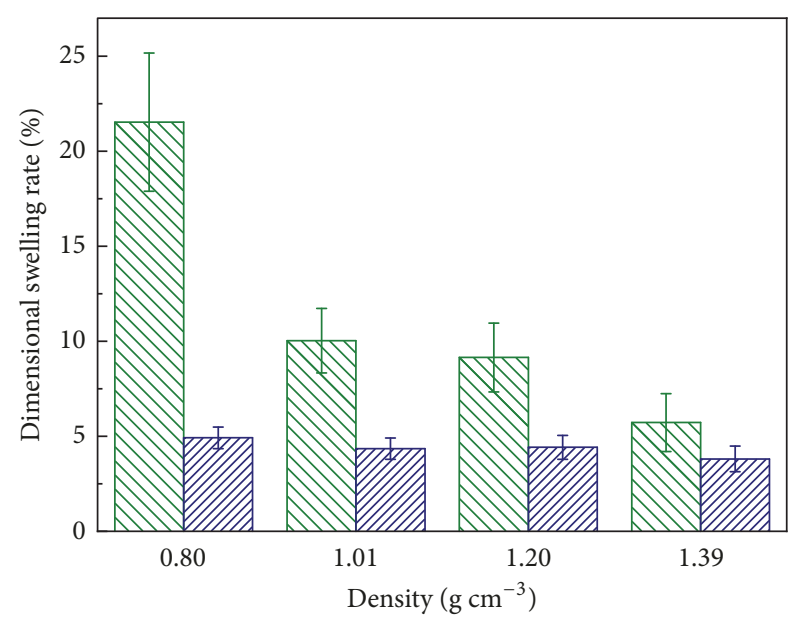

MIV Thickness

VIIIA Width

FIgURE 9: Dimensional swelling rate of scrimbers with different densities.

the swelling rate in width was only a little but much lower than that in thickness, no matter how high the density was. It would be seen from these results that the pine scrimbers possessed high dimensional stability.

\section{Conclusion}

In this study, pine scrimbers were prepared using the "newtype" scrimber technology. The oriented wood fiber mats (OWFMs) as basic units of scrimber exhibited the net-like structure consisting of many sharply oriented fibers. Due to a series of cracks on the surface, the permeability was four folds more than that of the untreated veneers. SEM micrographs revealed that the cell walls were compressed along the thickness direction, resulting in decreasing porosity. Both OWFMs and densification contributed to enhanced performance in the respect of mechanics and dimensional stability. For the scrimber at the density of $0.80 \mathrm{~g} \mathrm{~cm}^{-3}$, the flexural strength was much larger than that of many existed wood-based panels. As the density reached $1.39 \mathrm{~g} \mathrm{~cm}^{-3}$, the strength was increased to $198.92 \mathrm{MPa}$. Meanwhile, the water absorption rate and thickness swelling rate in boiled water were only $19 \%$ and $5.72 \%$, respectively. Such remarkable performance could endow the material with great prospects in the fields of highvalue applications.

\section{Data Availability}

The data supporting the findings of this study have been not available because it is part of the programs being in progress, and it will be further studied.

\section{Conflicts of Interest}

The authors declare that they have no conflicts of interest. 


\section{Acknowledgments}

This work was funded by the Special Funds for Basic Research and Operating Expenses of Central Level Public Welfare Scientific Research Institutes (CAFYBB2018SY031), Major Science and Technology Program of Hunan Province (No. 2017NK1010), and China Scholarship Council.

\section{References}

[1] D. Kretschmann, "Velcro mechanics in wood," Nature Materials, vol. 2, no. 12, pp. 775-776, 2003.

[2] M. Zhu, J. Song, T. Li et al., "Highly anisotropic, highly transparent wood composites," Advanced Materials, vol. 28, no. 26, pp. 5181-5187, 2016.

[3] K. Law and J. L. Valade, "Status of the utilization of jack pine ( Pinusbanksiana) in the pulp and paper industry," Canadian Journal of Forest Research, vol. 24, no. 10, pp. 2078-2084, 1994.

[4] Y. Andres, E. Dumont, P. Le Cloirec, and E. Ramirez-Lopez, "Wood bark as packing material in a biofilter used for air treatment," Environmental Technology, vol. 27, no. 12, pp. 12971301, 2006.

[5] T. Pakarinen, "Success factors of wood as a furniture material," Forest Products Journal, vol. 49, no. 9, pp. 79-85, 1999.

[6] M. H. Ramage, H. Burridge, M. Busse-Wicher et al., "The wood from the trees: the use of timber in construction," Renewable \& Sustainable Energy Reviews, vol. 68, pp. 333-359, 2017.

[7] J. J. Balatinecz and D. E. Kretschmann, "Properties and utilization of poplar wood," in Poplar Culture in North America (Part A), pp. 277-291, 2001.

[8] S. González-García, M. T. Moreira, G. Feijoo, and R. J. Murphy, "Comparative life cycle assessment of ethanol production from fast-growing wood crops (black locust, eucalyptus and poplar)," Biomass \& Bioenergy, vol. 39, pp. 378-388, 2012.

[9] M. Frey, D. Widner, J. S. Segmehl, K. Casdorff, T. Keplinger, and I. Burgert, "Delignified and densified cellulose bulk materials with excellent tensile properties for sustainable engineering," ACS Applied Materials \& Interfaces, vol. 10, no. 5, pp. 5030-5037, 2018.

[10] R. E. Hernández, A. Koubaa, M. Beaudoin, and Y. Fortin, "Selected mechanical properties of fast-growing poplar hybrid clones," Wood and Fiber Science, vol. 30, no. 2, pp. 138-147, 1998.

[11] J. H. Kwon, R.-H. Shin, N. Ayrilmis, and T. H. Han, "Properties of solid wood and laminated wood lumber manufactured by cold pressing and heat treatment," Materials and Corrosion, vol. 62, no. 10, pp. 375-381, 2014.

[12] W. Sun, H. Shen, and J. Cao, "Modification of wood by glutaraldehyde and poly (vinyl alcohol)," Materials and Corrosion, vol. 96, pp. 392-400, 2016.

[13] Z. Li, M. He, D. Tao, and M. Li, "Experimental buckling performance of scrimber composite columns under axial compression," Composites Part B: Engineering, vol. 86, pp. 203-213, 2016.

[14] E. Burdurlu, M. Kilic, A. C. Ilce, and O. Uzunkavak, "The effects of ply organization and loading direction on bending strength and modulus of elasticity in laminated veneer lumber (LVL) obtained from beech (Fagus orientalis L.) and lombardy poplar (Populus nigra L.)," Construction and Building Materials, vol. 21, no. 8, pp. 1720-1725, 2007.

[15] X. Dong, X. Zhuo, J. Wei, G. Zhang, and Y. Li, "Woodbased nanocomposite derived by in situ formation of organicinorganic hybrid polymer within wood via a sol-gel method,"
ACS Applied Materials \& Interfaces, vol. 9, no. 10, pp. 9070-9078, 2017.

[16] P. S. H'ng, L. Y. Chai, K. L. Chin et al., "Urea formaldehyde impregnated oil palm trunk as the core layer for three-layered board," Materials and Corrosion, vol. 50, no. 17, pp. 457-462, 2013.

[17] F. F. Kollmann, E. W. Kuenzi, and A. J. Stamm, Principles of Wood Science and Technology: II Wood Based Materials, Springer Science \& Business Media, 2012.

[18] M. He, D. Tao, Z. Li, and M. Li, "Mechanical behavior of doweltype joints made of wood scrimber composite," Materials, vol. 9, no. 7, p. 581, 2016.

[19] T. Joscak, A. Teischinger, U. Mueller, and R. Mauritz, "Production and material performance of long-strand wood composites-review," Wood Research, vol. 51, no. 3, pp. 37-49, 2006.

[20] Y. Zhang, X. Huang, Y. Zhang, Y. Yu, and W. Yu, "Scrimber board (SB) manufacturing by a new method and characterization of SB's mechanical properties and dimensional stability," Holzforschung, vol. 72, no. 4, pp. 283-289, 2018.

[21] Y. Zhang, Y. Huang, Y. Qi, and W. Yu, "Novel engineered scrimber with outstanding dimensional stability from finely fluffed poplar veneers," Measurement, vol. 124, pp. 318-321, 2018.

[22] Y. Wei, F. Rao, Y. Yu, Y. Huang, and W. Yu, "Fabrication and performance evaluation of a novel laminated veneer lumber (LVL) made from hybrid poplar," European Journal of Wood and Wood Products, vol. 77, no. 3, pp. 381-391, 2019.

[23] Y. Zhang, Y. Qi, Y. Huang, Y. Yu, Y. Liang, and W. Yu, "Influence of veneer thickness, mat formation and resin content on some properties of novel poplar scrimbers," Holzforschung, vol. 72, no. 8, pp. 673-680, 2018.

[24] K. Bayne, "Wood quality considerations for radiata pine in international markets," New Zealand Journal of Forestry, vol. 59, pp. 23-31, 2015.

[25] F. A. Kamke, "Densified radiata pine for structural composites," Maderas: Ciencia y Tecnologia, vol. 8, no. 2, pp. 83-92, 2006.

[26] C. A. Sologubik, L. A. Campañone, A. M. Pagano, and M. C. Gely, "Effect of moisture content on some physical properties of barley," Industrial Crops and Products, vol. 43, no. 5, pp. 762-767, 2013.

[27] M. I. Shams and H. Yano, "Compressive deformation of wood impregnated with low molecular weight phenol formaldehyde (PF) resin II: effects of processing parameters," Journal of Wood Science, vol. 50, no. 4, pp. 343-350, 2004.

[28] Y. H. Zhang, Y. M. Zhang, D. H. Ren, and Y. U. Wen-Ji, "Effect of manufacturing technology on scrimber performance," China Wood Industry, vol. 30, no. 5, pp. 31-34, 2016.

[29] X. Guo, Y. Lin, B. Na et al., "Evaluation of physical and mechanical properties of fiber-reinforced poplar scrimber," BioResources, vol. 12, no. 1, pp. 43-55, 2016.

[30] F. Arriaga-Martitegui, F. Peraza-Sánchez, and L. GarcíaEsteban, "Characteristic values of the mechanical properties of radiata pine plywood and the derivation of basic values of the layers for a calculation method," Biosystems Engineering, vol. 99, no. 2, pp. 256-266, 2008.

[31] C. Barbuta, P. Blanchet, A. Cloutier, V. Yadama, and E. Lowell, "OSB as substrate for engineered wood flooring," European Journal of Wood and Wood Products, vol. 70, no. 1-3, pp. 37-43, 2012.

[32] A. H. Juliana, M. T. Paridah, S. Rahim, I. Nor Azowa, and U. M. K. Anwar, "Properties of particleboard made from kenaf 
(Hibiscus cannabinus L.) as function of particle geometry," Materials \& Design, vol. 34, pp. 406-411, 2012.

[33] E. Baysal, M. K. Yalinkilic, M. Altinok, A. Sonmez, H. Peker, and M. Colak, "Some physical, biological, mechanical, and fire properties of wood polymer composite (WPC) pretreated with boric acid and borax mixture," Construction and Building Materials, vol. 21, no. 9, pp. 1879-1885, 2007.

[34] M. K. Dubey, S. Pang, S. Chauhan, and J. Walker, "Dimensional stability, fungal resistance and mechanical properties of radiata pine after combined thermo-mechanical compression and oil heat-treatment," Holzforschung, vol. 70, no. 8, pp. 793-800, 2016.

[35] Y. Xiao, R. Yang, and B. Shan, "Production, environmental impact and mechanical properties of glubam," Construction and Building Materials, vol. 44, pp. 765-773, 2013.

[36] A. Krishnan and L. R. Xu, "Systematic evaluation of bonding strengths and fracture toughnesses of adhesive joints," The Journal of Adhesion, vol. 87, no. 1, pp. 53-71, 2011.

[37] Y. Yu, X. Huang, and W. Yu, "A novel process to improve yield and mechanical performance of bamboo fiber reinforced composite via mechanical treatments," Composites Part B: Engineering, vol. 56, no. 1, pp. 48-53, 2014.

[38] I. M. de Rosa, J. M. Kenny, D. Puglia, C. Santulli, and F. Sarasini, "Morphological, thermal and mechanical characterization of okra (Abelmoschus esculentus) fibres as potential reinforcement in polymer composites," Composites Science and Technology, vol. 70, no. 1, pp. 116-122, 2010.

[39] A. J. Stamm, "Movement of fluids in wood-part I: flow of fluids in wood," Wood Science and Technology, vol. 1, no. 2, pp. 122-141, 1967.

[40] S. Fukuta, F. Asada, and Y. Sasaki, "Manufacture of compressed wood fixed by phenolic resin impregnation through drilled holes," Journal of Wood Science, vol. 54, no. 2, pp. 100-106, 2008. 


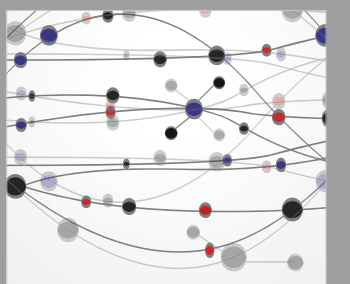

The Scientific World Journal
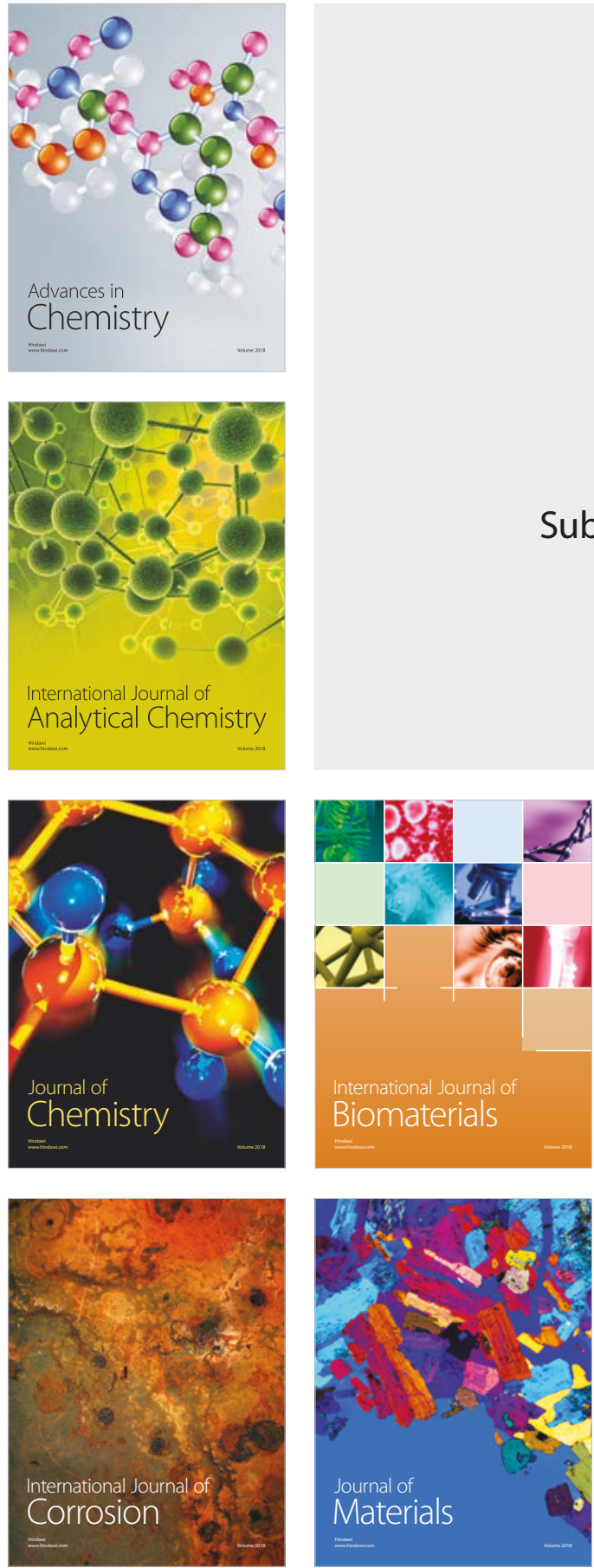

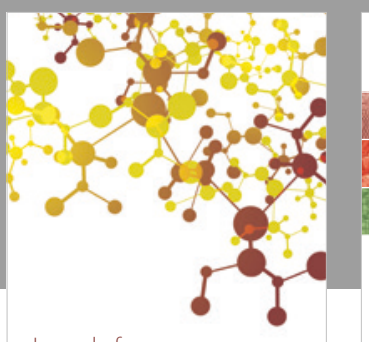

Journal of

Applied Chemistry
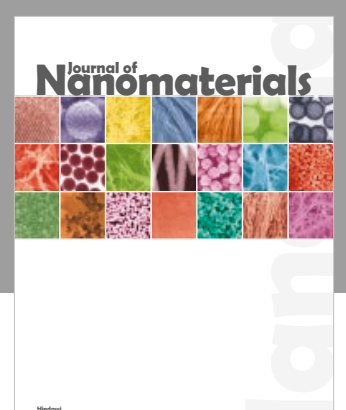

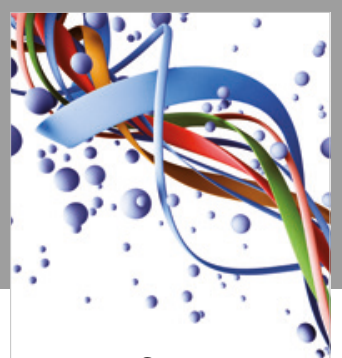

Scientifica

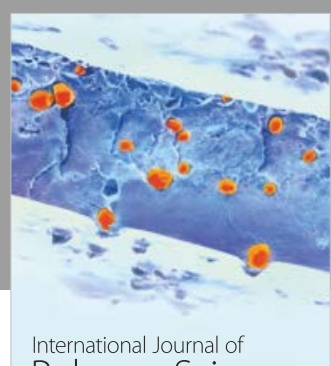

Polymer Science

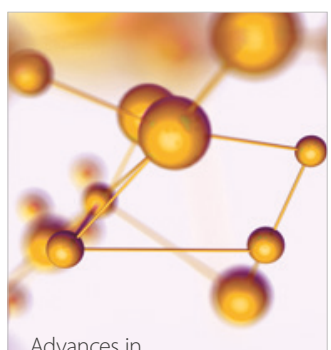

Physical Chemistry
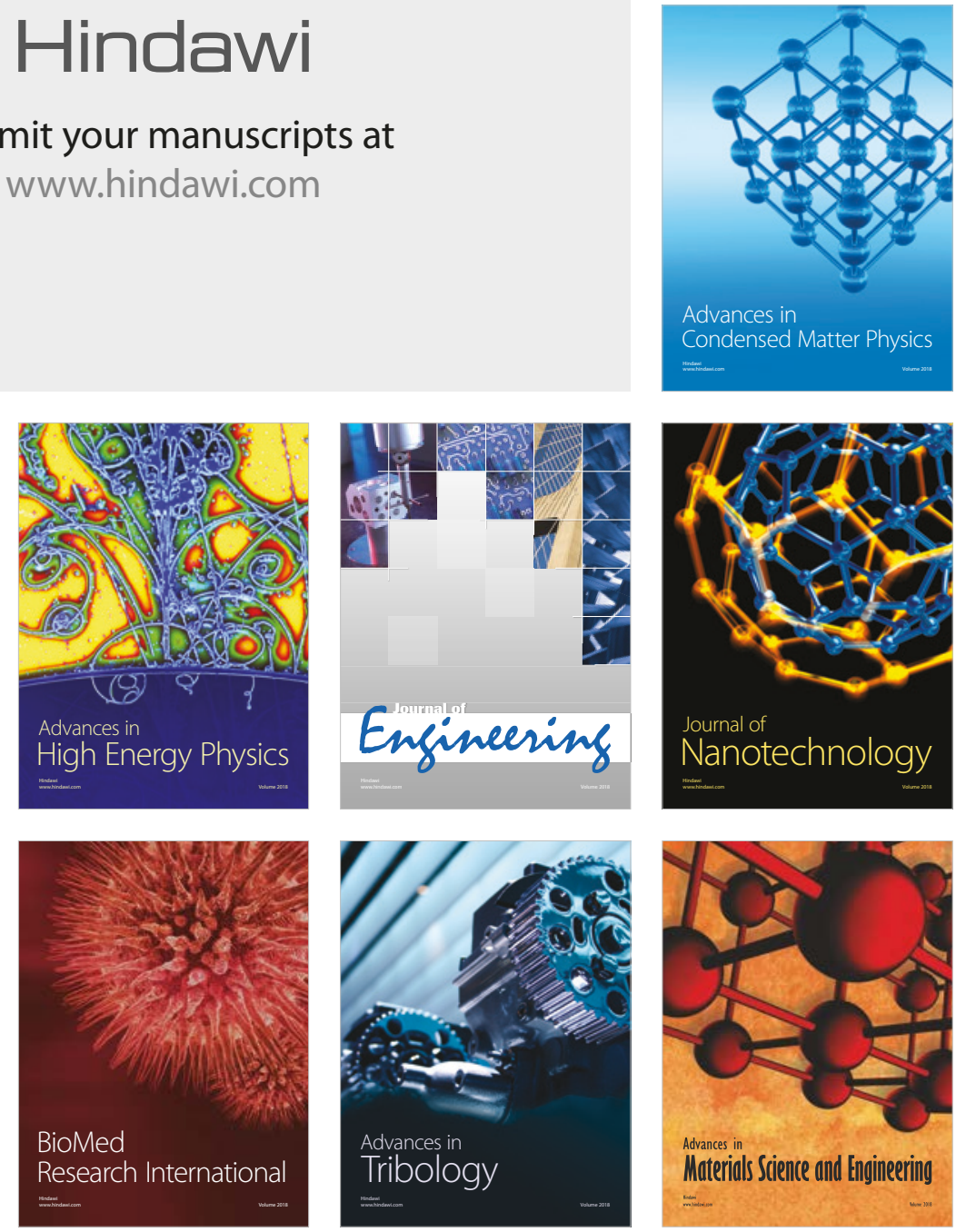